\title{
Blended Learning in Financial Management 1
}

\author{
Denny Yohana ${ }^{1, *}$ Dian Yuni Anggraini ${ }^{2}$ \\ ${ }^{1}$ Accounting Department, Andalas University, Padang, West Sumatra, Indonesia \\ *Corresponding author. Email: dennyyohana@eb.unand.ac.id
}

\begin{abstract}
Blended learning is a combination of conventional learning models usually done directly with e-learning internet network-based learning models. This method provides several conveniences in the teaching and learning process, both process and materials. It is hoped that this method can improve student performance. The observation and survey method are used in this research on the Financial Management 1 class, which consists of 30 students; we find the impact of using blended learning. The results obtained were that only $33.7 \%$ of students liked this method, student performance was slightly increased, and participation in the class activity is also increased. Students feel burdened with more self-study and assigned assignments.
\end{abstract}

Keywords: Blended learning, Student performance, Learning effectivenes.

\section{INTRODUCTION}

Financial management course 1 is a compulsory subject for accounting and management at the Andalas University Faculty of Economics, which is given in the third semester. This course is a prerequisite for taking the Financial Management II course. Before taking this course, students must have passed an introductory management course with a minimum D Grade.

In this course, students learn basic principles of financial management, so students must understand financial reports. Students are also given knowledge on how to forecast, plan, and financial budget, calculate the cost of capital, then also understand current asset management which consists of cash, accounts receivable and inventories. The course learning outcomes are:

1. Mastering financial management concepts, principles and techniques covering financial decisions

2. Mastering financial management concepts, principles, and techniques are covering the time value of money.

3. Mastering financial management concepts, principles and techniques including capital budgeting

4. Mastering financial management concepts, principles and techniques covering working capital requirements

5. Mastering financial management concepts, principles and techniques covering working capital requirements

6.Mastering the principles of investing in financial assets
This learning outcome is also in line with the learning outcomes of the study program which states that graduates of the Andalas University Accounting Study Program show a responsible attitude towards work in their field of expertise independently and internalize the spirit of independence, struggle, and entrepreneurship for that after taking this course students have sufficient abilities good in financial management.

Teaching materials developed at this time are in the form of powerpoints for each meeting as most of the materials are taken from predetermined books.

The current learning method uses a conventional approach; before students enter the class according to schedule, students make a summary of the courses that will be studied that day. Then the lecturer explains the material, questions, answers, discussion after that, gives assignments independently or in groups.

The assessment is given in the form of:

- Final exams with a weight of $35 \%$ are usually in the form of cases and essays

- Midterm exams with a weight of $35 \%$ are usually the case and essay questions

- Activity in class weighs $10 \%$

- Assignments and quizzes in class weigh $20 \%$

The distribution of scores obtained by students in the last 2019/2020 odd semester is as follows: 


\begin{tabular}{|c|c|}
\hline score & Share (\%) \\
\hline A & 16 \\
\hline A- & 8 \\
B + & 11 \\
B & 16 \\
B- & 14 \\
C + & 4 \\
C & 15 \\
D & 16 \\
E & 0 \\
\hline amount & 100 \\
\hline
\end{tabular}

From the data above, it can be seen that the number which got the $\mathrm{D}$ and $\mathrm{C}$ scores was relatively high. It is due to students' low participation in discussions, and they do not like making summaries. In discussion activities, usually, only a few students are active while the others are silent and look uninterested. In increasing students' understanding, it is necessary to improve learning so that student understanding increases which are reflected in their grades.

At this time, advances in information technology have made it possible to develop online methods for learning, for this reason, we want to do engaging blended learning for students so that learning outcomes can be achieved. For that matter, we want to develop a blended learning method that combines face-to-face classrooms with synchronous and unsynchronous online lectures.

The formulation of the research problems are (1) how the performance of students using Blended learning (2) are students more active when using blended learning than conventional methods? (3) what is the effectiveness of online learning according to students, and (4) what are students' expectations about the implementation of online lectures

\subsection{Blended learning}

Asmendri and Milya (2018) state that a learning model is needed to achieve learning goals, which is a specific design designed in such a specific way. The increasingly varied mobility of human life and the presence of various new technologies are the backgrounds for the blended learning model. The emergence of this learning model is also an innovation in responding to globalization and the challenges of changing times.

Uno (2011) states that blended learning is a term for mixing conventional learning models usually done face- to-face with internet network-based learning models and commonly known as e-learning. Initially, blended learning was used to describe subjects that tried to combine face-to-face learning with online or online learning (Sjukur, 2012). Furthermore, various terms can also be equated with blended learning, such as hybrid learning or mixed-mode learning. These various terms contain the same meaning, namely a combination, mixture or combination of learning.

Various definitions describe the notion of blended learning. In general, blended learning refers to learning that combines or mixes face-to-face learning and computer-based learning (online and offline) (Dwiyogo, 2011). More specifically, Thorne (2003: 2) interprets blended learning as:

"It represents an opportunity to integrate the innovative and technological advances offered by online learning with the interaction and participation offered in the best of traditional learning."

Then, Bersin (2004: 56) defines blended learning as:

"The combination of different training" media "(technologies, activities, and types of events) to create an optimum training program for a specific audience. The term "blended" means that the traditional instructor-led training is being supplemented with other

electronic formats. In the context of this book, blended learning programs use many different forms of $e$ learning, perhaps complemented with instructor-led training and other live formats. "

Furthermore, Whitelock \& Jelfs (2003) in Ekayati (2018) provide three definitions for blended learning, namely: (a) The integrated combination of traditional learning with web-based online approaches; (b) The combination of media and tools employed in an eLearning environment; and (c) The combination of several pedagogic approaches, irrespective of learning technology use.

Based on this view, it can be said that blended learning exists as a combination of the characteristics 
of traditional learning and electronic learning environments. Also, this learning model combines aspects of blended learning (electronic format) such as web-based learning, video streaming, synchronous and asynchronous audio communication with traditional "face-to-face" learning.

The blended learning model is one of the priorities, especially nowadays. It happens for several reasons. Purnomo, Ratnawati \& Aristin (2016) stated that several possible reasons are (a) it can be applied to anyone, especially those who have high mobility and find it challenging to continue to meet face to face with educators or lecturers; (b) as a means of learning together for those who feel they need additional material; (c) less satisfied with conventional learning in the classroom, because with blended learning they can

quickly get new and even more up to date materials from various sources and even experts from all over the world.

Based on this explanation, the blended learning method can be an excellent solution to meet educational needs. Moreover, each student's learning and self- exploration are efficient (Saifuddin, 2017). However, this method also has drawbacks. One of them is having a time commitment because when it is not face-to-face (traditional), there is no separate time to learn. In essence, the purpose of the blended learning that is implemented is to get the "best" learning by combining the various advantages of each component where the conventional method allows for interactive learning while the online method can provide material directly without the limitations of space and time. So that maximum learning can be achieved.

\section{METHODS}

This research is a descriptive study with observation and survey methods conducted on financial management class

Financial management 1 is a compulsory subject for semester three students. The number of students in this class is 30 people. The steps taken are as follows:

1. Surveying student readiness in implementing blended learning

2. Development of output-based Semester Learning Plans

3. Developing teaching materials

4. Developing teaching methods

5. Prepare learning media in the form of videos

6. Carry out lectures

7. Conduct an assessment
8. Conducting a survey of the implementation of learning to students

9. Draw a conclusion.

\subsection{Learning Methods}

The blended learning method that is carried out before the midterm exam consists of 7 meetings with details of 2 face-to-face lectures through the Zoom application, three synchronous online and two asynchronous online. All teaching materials have been provided to i-learn universities. The first face-to-face meeting with zoom explains lecture methods and discusses the basic concepts of Financial Management 1. The second, fourth and sixth meetings are synchronous online meetings, while meetings 3 and 5 are asynchronous online meetings.

During the half-semester, the teaching materials are equipped with learning videos. The Material in the form of PPT and compulsory books is also expected to help students in their studies.

The assignments given to students are also handled variously, such as making assignments in the form of videos and weekly assignments in the form of financial cases.

Assessment is also carried out in the form of quizzes and discussions on chat forums.

\subsection{Survey}

At the first and seventh meetings, a survey of students was conducted. The first questionnaire is a list of questions about student readiness in online lectures, including questions:

1. Online student readiness

2. Readiness to provide internet quota

3. Barriers that have occurred during online lectures

4. Benefits of studying online

5. Student preference for online lecture support methods and facilities

The second questionnaire given in lecture 7 contains questions to see the learning experience of students with blended learning. The questions asked to include:

1. The level of student activity in reading and studying the material independently

2. Benefits are felt with blended lectures

3. Benefits of instructional videos

4. Applications that students like for lectures 

5. Task load
6. Understanding of the material
7. The preferred blended learning comparison
8. The hope of studying online in the future

Conclusions were drawn based on lecturers' Assessments and student opinions on the implementation of online lectures.

\section{RESULTS AND DISCUSSION}

From the results of the first survey conducted, it was found that only $22.7 \%$ of students did not experience problems with internet access, 72.7\% sometimes experienced internet access difficulties, and $5.6 \%$ experienced internet access difficulties. The form of Synchronous online lectures is liked by $40.9 \%$ of students, and the rest likes the combination of synchronous and asynchronous so that no student likes unsynchronous. It is because students find it difficult with time. After all, other courses must be done. Meanwhile, the preferred application for students is lectured via the WhatsApp application, followed by zooming and videos from YouTube. Students also find it challenging to use I-Learn prepared by the university, which is often constrained.

\subsection{Student performance}

From the observations made on the discussion of assignments and quizzes and compared to the conventional method last semester, it can be seen that conventional methods are more likely to collect assignments on time. It is because by using e-learning, students are still allowed to upload assignments even though the assignment submission time has ended. Moreover, the trend in online lectures has decreased over time the number of students submitting assignments on time from $96 \%$ to $73 \%$.

From the observation of the discussion, online lectures students are more active than conventional lectures. Students are more active in asking and answering questions that are given. However, the answers given are sometimes not quite right. For counting questions, many students complained that they did not understand even though it had been explained via video.

Quizzes are usually given at the beginning or end of class. Students are required to read the material before lectures start so that they can answer the quiz correctly.

The survey results showed that $6.7 \%$ of students felt very burdened by the assignments given by the lecturers, $36.7 \%$ felt burdened, 43.3 were neutral, so only $13.3 \%$ of students felt that they were not burdened with tasks. In each meeting, the lecturer assigns assignments to increase student understanding about the materials. Assignments per week consist of 2 to 5 questions. Because other courses also provide assignments, students feel less time to look for answers to assignments. Furthermore, the library is also not accessible online. The task of making videos can be done by students well.

\subsection{Student activity}

Student activity is seen from attendance list and activity to read material before class. The mean attendance was $96 \%$. A total of 2-4 people are absent from lectures each week. Activeness following the discussion is quite good; the response is also quite fast.

Based on the survey results, only $3.3 \%$ of students were very in reading and looking for material. As many as $20 \%$ are active in reading the material, $40 \%$ are neutral, and the rest are not diligent in reading the material. One of the students commented that he hoped that studying online would not make him lazier to study. It seems that students are less motivated to learn. The survey results also showed that $10 \%$ became very inactive in the learning process, $30 \%$ were inactive, and $46.7 \%$ answered neutrally while the rest were quite more active.

\subsection{Learning effectiveness}

The effectiveness of learning, according to students, is seen from the survey given to students. The quiz questions were given in the form of a summative test which was not too difficult to answer. Students have difficulty with the topic which is need mathematical sollution.

As many as $6.7 \%$ of students liked the videos provided by the lecturers, and $36.7 \%$ liked them. As many as $43.3 \%$ are neutral, and the remaining $13.3 \%$ do not like the learning videos. As many as $13.3 \%$ of students understand all the topics studied, and $46.7 \%$ are neutral, and the rest do not understand the topics given.

\subsection{Student Expectations for Blended Learning}

Based on the questions given to students, there are several expectations related to blended learning which are summarized as follows:

1. Students prefer the proportion of blended learning 50:50 to $30: 70$

2. $46.7 \%$ of students prefer lectures in class compared to online

3. $36.3 \%$ of students like online lectures because they are more flexible with time and can always follow lectures

4. Online lectures will run well if all facilities are available properly, such as more complete 
5. materials and all materials equipped with interesting learning videos.

6. Internet connection dramatically affects the success of blended learning.

The overall assessment of students with the Financial Management 1 course is quite useful because it is given a pretty good explanation when zooming in the face to face and the learning video is quite helpful; the assignments are quite varied. Student performance and activity are also quite good, even though they feel overwhelmed.

One limitation of this research is that the blended lecture process is not carried out directly in the class, but directly through the Zoom application, so there is no direct interaction between lecturers and students. Also, sometimes in answering survey questions, it seems that students do not focus only on financial management one courses, but are also influenced by the current lecture process in general. Where they are forced to study online, with several lecturers giving many assignments, and they are limited in finding reading sources in the form of books. If the practice of blended learning is carried out in normal circumstances, the results obtained today might be different. Furthermore, if students are used to studying online, it may be easier for them to adapt.

\section{CONCLUSION}

Blended learning is a teaching method that combines face-to-face class meetings with the use of information technology. The goal of online learning is to foster a learner's enthusiasm in students because by getting used to online lectures, they can take advantage of technological advances and discipline themselves to learn not at the specified time. Students in Financial Management 1 class are used as objects to seeing the effectiveness of learning by using blended learning. The results showed quite good results. There was an increase in the activity and creativity of students and lecturers. In terms of effectiveness, it still needs improvement, especially for the topic of calculation.

\section{ACKNOWLEDGMENT}

This work was supported by Lembaga Pengembangan Pendidikan dan Penjaminan Mutu Universitas Andalas year 2020 research Grant.

\section{REFERENCES}

[1] Asmendri \& Sari Milya. (2018). Analysis of Learning Theories on Blended Learning Model Development with Facebook (MBL-FB). Natural Science Journal. Vol. 4, No. 2, 604-615.

[2] Sneezing, J. (2004). The Blended Learning Book: Best Practices, Proven Methodologies, and Lessons
Learned. San Francisco: Pfeiffer Publishing.

[3] Dwiyogo, WD (2011). Blended Learning Learning.(Online).

(http://id.wikibooks.org/w/index.php?title $=$ Pemb elajaran_Berbasis_Blended_Learning\&printable $=$ yes., accessed on 8 October 2020).

[4] Ekayati, Rini. (2018). Implementationof Edmodo Application-Based Blended Learning Method. Edutech Journal. Vol. 4, No. 2.

[5] Purnomo, Agus, Nurul Ratnawati \& Nevy Farista Aristin. (2016). Development of Blended Learning in Generation Z. Journal of Social Studies Learning Theory and Praxis. Vol. 1, No. 1.

[6] Saifuddin, Much Fuad. (2017). E-Learning in Student Perception. Varia Education. Vol. 29, No. 2, 102-109.

[7] Sjukur, Sulihin B. (2012). The Influence of Blended Learning on Learning Motivation and Student Learning Outcomes at the SMK Level. Journal of Vocational Education, Vol 2, No. 3.

[8] Thorne, K. (2003). Blended Learning: How to Integrate Online and Traditional Learning. London: Kogan Page Publishers.

[9] Uno, B. Hamzah. (2011). Learning model. Jakarta: Earth Literacy. 